\title{
KEARIFAN TEMPATAN DALAM PENDIDIKAN KANAK-KANAK: SOROTAN TERHADAP GARIS PANDUAN HUKUMAN ROTAN DI KEMENTERIAN PENDIDIKAN MALAYSIA (KPM)
}

\section{Local Wisdom in Children Education: A Review of the Practice of Whipping Punishment in Ministry of Education Malaysia (MOE)}

\author{
Siti Amalina Ahmad Khairundin* \\ Shahidra Abdul Khalil** \\ Mumtazah Narowi***
}

\begin{abstract}
Whipping is a punishment method commonly practiced in educating that is deeply rooted in the Malaysian society. However, there are inclinations on banning this educational punishment on children, for example as in Article 29 of the Children Rights Convention. The objective of this paper is to review the historical practice of educational whipping punishment in Malaysia while making use of local
\end{abstract}

* Postgraduate Student, Department of Fiqh and Usul, Academy of Islamic Studies, University of Malaya, and Lecturer, Department of General Studies and Language, Centre for Foundation and General Studies, University of Selangor, amalina@unisel.edu.my

** Senior Lecturer, Department of Fiqh and Usul, Academy of Islamic Studies, University of Malaya, shahidra@um.edu.my

*** Lecturer, Department of General Studies and Language, Centre for Foundation and General Studies, University of Selangor, azah83my@unisel.edu.my 
wisdom in finding a middle ground of practicing whipping in schools. Hence, a qualitative method was adopted in this research by referring to primary sources from the Malaysian Education Ministry and to secondary sources such as academic articles. The data collected was analysed using thematic and descriptive approaches. The findings indicate that the objectives, as commented by the Committee of the Rights of Children in 2001, was not fully accepted. This shows that the element of local wisdom in balancing the punishment practice and the guidelines are also constructed in line with Islamic Legislation.

Keywords: Education, Discipline, Children, Whipping, Local Wisdom

\section{PENDAHULUAN}

Kearifan tempatan adalah nilai yang wujud dalam sesebuah masyarakat dan diyakini kebenarannya sehingga ia menjadi acuan dalam tingkah laku seharian masyarakat setempat. ${ }^{1}$ Secara lebih khusus, kearifan tempatan boleh dikatakan sebagai sebuah bentuk pengetahuan yang mempunyai ciri-ciri kebijaksanaan dalam tradisi lama dan amalan masyarakat tempatan yang diwarisi secara turun temurun daripada generasi ke generasi melalui transmisi budaya. ${ }^{2}$ Menurut Cecep Eka Permana, kearifan tempatan merangkumi enam jenis dimensi seperti (i) nilai tempatan (ii) solidariti kelompok (iii) sumber tempatan (iv) pengetahuan tempatan (v) keterampilan tempatan dan (vi) pengambilan keputusan tempatan. ${ }^{3}$

Dalam makalah ini, perbincangan mengenai pendidikan kanak-kanak dalam kalangan masyarakat Melayu dihuraikan menerusi dimensi nilai. Dimensi ini merujuk kepada cara sesebuah masyarakat menyusun kehidupan mengikut nilai atau

1 Mohd Izuddin Ramli dan Mohamad Zaini Abu Bakar, "Kearifan Tempatan dalam Institusi Sekolah Pondok di Malaysia", dalam Ilmu, Tradisi dan Kelestarian dalam Kearifan Tempatan, ed. Salasiah Che Lah dan Norizan Esa (Pulau Pinang: Penerbit Universiti Sains Malaysia, 2015), 41.

2 Ibid.

3 Ibid. 
kepercayaan yang telah disepakati bersama. Peribahasa Melayu yang berkaitan dengan aspek pendidikan anak-anak dibincangkan bagi mengupas pandangan semesta dan pegangan masyarakat dalam hal ini. Seterusnya, kertas ini juga menyorot kebijaksanaan kerajaan melalui Kementerian Pendidikan Malaysia (KPM) dalam mempertahankan nilai yang telah dipegang secara turun temurun mengenai kaedah pendidikan atau pendisiplinan anak-anak iaitu melalui hukuman rotan. Justeru kearifan tempatan dalam hal ini dibincangkan menerusi dimensi pengambilan keputusan tempatan. Ia bermaksud kaedah tempatan yang khusus digunakan oleh masyarakat untuk membuat sesuatu keputusan yang secara umumnya bersifat politik.

Bagi menonjolkan kearifan tempatan, cabaran-cabaran dan tentangan nilai-nilai moden terhadap kaedah pendidikan anak melalui hukuman rotan turut dibincangkan. Cabaran utama dalam hal ini adalah undang-undang antarabangsa mengenai larangan untuk mengenakan hukuman dera seperti rotan ke atas kanakkanak kerana dianggap boleh memalukan dan menjejaskan kehormatan diri dan hak kanak-kanak. Selain itu, nilai-nilai yang mempengaruhi budaya atau nilai masyarakat Melayu secara turun-temurun dalam aspek ini iaitu ajaran Islam turut dikupas. Dengan itu, cara masyarakat tempat beradaptasi, berintergrasi dan memelihara nilai yang telah didokong ini dapat dijelaskan.

\section{KAEDAH PENDIDIKAN ANAK-ANAK MELALUI HUKUMAN DALAM KALANGAN MASYARAKAT MELAYU TERDAHULU}

Kaedah pendidikan anak oleh masyarakat Melayu terdahulu ada dibincangkan antaranya oleh Rabiatul Adawiyah et.al yang mengkaji penerapan nilai melalui pendidikan secara tidak formal masyarakat Melayu. Temu bual yang dijalankan dengan warga emas dalam kajian tersebut, merumuskan bahawa dalam kalangan masyarakat Melayu terdahulu, ibu bapa memainkan peranan yang besar dalam menerapkan pendidikan nilai terhadap anakanak. Masyarakat Melayu terdahulu seperti masyarakat Asia disimpulkan mempunyai gaya asuhan yang menekankan kuasa dominan ibu bapa khsususnya bapa, manakala hubungan dengan ibu adalah lebih santai. Ibu bapa secara umumnya melakukan 
kawalan yang ketat serta pemantauan yang menyeluruh terhadap anak-anak. ${ }^{4}$

Pendekatan yang diambil oleh ibu bapa masyarakat Melayu terdahulu dalam menangani pendidikan anak-anak adalah tegas. Walau bagaimanapun, ini tidak bermaksud kekerasan merupakan pendekatan yang dominan. Bagi anak-anak yang lebih besar, biasanya pendekatan nasihat dan teguran dilakukan sesuai kematangan usia anak-anak. Manakala bagi anak-anak yang lebih kecil, pendekatan yang lebih keras dilakukan bagi tujuan mendisiplinkan mereka. Hukuman dikenakan hanya ke atas anakanak yang terlalu nakal, sukar dikawal dan degil. Antara bentuk hukuman yang dikenakan termasuklah rotan, duduk di luar rumah untuk satu jangka masa yang lama dan hukuman berorientasikan kemahiran hidup. ${ }^{5}$

Dapatan kajian ini dilihat selari dengan pandangan semesta masyarakat Melayu yang boleh dikesan daripada peribahasa Melayu. Peribahasa merupakan satu bentuk bahasa yang merakamkan perihal, keadaan, sifat, cara, kejadian, peristiwa dan sebagainya menggunakan medium yang puitis, ringkas, berirama dan sebagainya. Ramai pengkaji terdahulu menyatakan bahawa bahasa tidak sahaja menentukan kebudayaan tetapi juga jalan fikir penuturnya ${ }^{6} \mathrm{Hal}$ ini kerana peribahasa Melayu telah berkembang seiring dengan kelahiran bangsa Melayu dan sehingga kini masih digunakan dalam kalangan masyarakat. Malah ada yang menjadikan peribahasa Melayu sama ada berbentuk simpulan bahasa, perumpamaan, bidalan, pepatah dan kata-kata hikmat sebagai falsafah dan pegangan hidup. Zaitul Akma menjelaskan bahawa dalam peribahasa Melayu, aspek etika ditegaskan dengan tujuan mendidik dan meningkatkan adab susila dalam kalangan

4 Rabiatul Adawiyah et. al, "Pendekatan Penerapan Pendidikan Nilai Menerusi Pendidikan Tidak Formal Masyarakat Melayu Terdahulu", dalam Merakayasa Kearifan Tempatan: Budaya, Pelancongan, Arkeologi dan Sejarah, ed. Nazaruin Zainun dan Darlina Md. Naim (Pulau Pinang: Penerbit Universiti Sains Malaysia, 2014), 47-49.

5 Ibid, 49.

6 Wan Rafaei Abdul Rahman, "Peribahasa Sebagai Sumber Epistimologi Melayu: Satu Singkapan Terhadap Etika Kerja", dalam Prosiding Simposium Pengetahuan Pribumi anjuran Akademi Pengajian Melayu Universiti Malaya pada 15 April 2015, 70. 
bangsa Melayu supaya mengamalkan tingkah laku yang benar dan wajar. $^{7}$

Dalam koleksi peribahasa Melayu, beberapa peribahasa dapat menjelaskan pandangan orang Melayu terhadap pendidikan nilai ke dalam diri anak-anak. Antara peribahasa yang sangat masyhur dalam hal ini adalah "Melentur buluh, biarlah dari rebungnya." Peribahasa ini mempunyai maksud yang hampir sama dengan peribahasa lain yang berbunyi "Sedang rebung baik dipatah, jadi buluh melepuh jari" dan "Masa lagi rebunglah hendak dilentur, jangan dinantikan sampai menjadi aur." Semua peribahasa ini membawa maksud sewaktu kecil anak-anak perlu diajar dan dididik, jangan ditunggu sehingga sudah menjadi besar. ${ }^{8}$ Daripada peribahasa ini, dapat difahami masyarakat Melayu menitik beratkan pendidikan nilai ke atas anak-anak semenjak kecil lagi kerana apabila anak sudah membesar, pendidikan yang baru mahu diterapkan akan menjadi sukar dan kurang berkesan kerana anak tersebut telah mempunyai kebiasaan tingkah laku tertentu.

Aspek pendekatan pendidikan orang Melayu pula, dapat difahami melalui beberapa peribahasa seperti "Sayang anak tangan-tangankan, sayang isteri tinggal-tinggalkan." Maksud kepada pepatah ini ialah anak dan isteri yang dimanjakan berlebihlebihan akan menjadi mengada-ngada. ${ }^{9}$ Selain itu, terdapat juga peribahasa yang berbunyi "Sayang anak dilecuti, sayang negeri ditinggalkan." Peribahasa berbentuk pepatah ini bermaksud sayang anak dimarahi, sayang negeri, pergi merantau ke negeri lain. ${ }^{10}$ Kedua-dua pepatah ini dapat menggambarkan pendekatan orang Melayu dalam mendisiplinkan anak iaitu tidak membiarkan kesalahan mereka berlarutan, sebaliknya teguran dan hukuman yang boleh mendidik seperti hukuman rotan perlu dilakukan. Pepatah pertama juga memberikan peringatan kepada masyarakat

7 Zaitul Azma, Peribahasa Melayu: Penelitian Makna dan Nilai (Serdang: Penerbit Universiti Putra Malaysia, 2011), 9.

8 Kamus Istimewa Peribahasa Melayu, laman sesawang rasmi Pusat Persuratan Rujukan Melayu, dicapai 6 Disember 2018, http://prpm. dbp.gov.my/Caril ?keyword=buluh\&d=287324\&.

9 Abdullah Hassan dan Ainon Mohd, Kamus Peribahasa Kontemporari (Bentong: PTS Publications \& Distributors Sdn. Bhd., 2003), 358.

10 Zaitul Azma, Peribahasa Melayu, 674. 
mengenai kesan buruk terhadap tingkah laku anak-anak sekiranya teguran dan hukuman tidak dilakukan oleh ibu bapa.

Gesaan kepada pendekatan yang keras dalam dua pepatah di atas walau bagaimanapun diimbangi dengan peribahasa lain. Dalam aspek hubungan ibu bapa dan anak-anak, wujud perumpaan yang berbunyi "bagai menatang minyak yang penuh." Perumpamaan ini membawa maksud anak dipelihara dengan penuh kasih sayang. Ini menonjolkan nilai kasih sayang dalam kalangan masyarakat Melayu ${ }^{11}$ yang dapat dirumuskan menyayangi anak-anak dengan sepenuh hati. Justeru, kesimpulan yang dapat dibuat daripada semua peribahasa berkaitan di atas ialah pendisiplinan anak-anak melalui hukuman dalam kalangan masyarakat Melayu adalah dianggap sebagai sesuatu yang wajar demi kebaikan anak-anak. Malah perlu dilakukan semenjak kecil. Pendidikan terbaik juga adalah salah satu tanda kasih sayang ibu bapa terhadap anak-anaknya. Selain itu, dapat difahami juga bahawa walaupun hukuman fizikal boleh dikenakan ke atas anakanak demi membentuk peribadi dan menanamkan nilai dan ilmu kepada diri mereka, masyarakat Melayu tidak cenderung dan berlebih-lebihan dalam melakukan hukuman yang keras kerana anak-anak dihargai dan disayangi sepenuhnya.

Penerimaan ibu bapa terhadap kaedah pendispilinan anakanak melalui hukuman ini, bukan hanya pada penerapan nilai melalui pendidikan tidak formal yang dimainkan peranannya oleh para ibu bapa, kaum keluarga mahupun masyarakat. Masyarakat Melayu terdahulu juga boleh menerima hukuman yang dikenakan ke atas anak-anak mereka oleh para guru melalui sistem pendidikan formal. Pada zaman dahulu, pendidikan formal dalam kalangan masyarakat Melayu dipelopori oleh madrasah dan sekolah pondok. Berdasarkan literatur, budaya penghormatan dan kepatuhan kepada tok guru atas dasar pengetahuan dan karisma yang dimiliknya mewujudkan suasana disiplin di antara pelajar dengan guru. ${ }^{12}$

Ibid, 165.

12 Mohd Izuddin Ramli "Kearifan Tempatan dalam Institusi Sekolah Pondok di Malaysia", 41. 


\section{HUKUMAN ROTAN KEPADA KANAK-KANAK MENURUT KEMENTERIAN PELAJARAN MALAYSIA}

Secara realitinya, zaman sekarang berbeza dengan zaman dahulu walaupun hukuman yang dikenakan oleh guru ke atas pelajar adalah lebih teruk dari sekarang. Pada zaman dahulu, guru bukan sahaja merotan, malah menampar, mencubit, memukul muridmurid dengan kuat sehingga meninggalkan kesan. Kebanyakan murid masih lagi menghormati bekas guru mereka dan sentiasa terhutang budi kerana mereka berasa insaf atas hukuman yang diberikan dan menganggap ia adalah sebahagian daripada didikan kepada mereka. Kini, guru semakin terdedah dengan tindakan undang-undang kerana ibu bapa telah mula peka terhadap undang-undang terutamanya yang melibatkan hukuman ke atas anak mereka. Justeru, guru besar atau pengetua yang merupakan pentadbir sekolah perlu peka kepada situasi ini dan sentiasa menitik beratkan pelaksanaan jenis hukuman mesti berpandukan kepada peraturan yang telah ditetapkan oleh Kementerian Pendidikan Malaysia.

Di peringkat sekolah, disiplin merupakan suatu peraturan yang boleh dikenakan ke atas pelajar dengan tujuan mengawal perbuatan atau tingkah laku mereka melalui hukuman atau pun ganjaran. ${ }^{13}$ Konsep disiplin secara umumnya adalah merangkumi latihan membentuk, membetul, ataupun melengkapkan suatu sistem peraturan berkaitan perbuatan atau tingkah laku mengikut peraturan-peraturan yang telah diwujudkan. Dalam konteks undang-undang dan peraturan disiplin sekolah di Malaysia, telah dipraktikkan berdasarkan kepada tiga rujukan utama ${ }^{14}$ iaitu:

i. Peraturan-peraturan Pelajaran (Disiplin Sekolah) 1959, iaitu peraturan yang dibuat berdasarkan kuasa-kuasa yang diberi oleh seksyen 116, Ordinan Pelajaran 1957.

ii. Buku-buku panduan pengurusan disiplin yang diterbitkan oleh Kementerian Pendidikan Malaysia.

13 Mohd. Ismail Othman, Undang-undang untuk Pengetua dan Guru Besar (Kuala Lumpur: PTS Professional, 2008), 64.

14 Nasrul Hisyam Nor Muhamad \& Zarina A Rashid, "Peraturan dan Undang-Undang Kawalan Disiplin Murid di Malaysia”, dicapai 17 Mei 2019, Malaysian Online Journal of Education (2017), 1-11. 
iii. Surat-surat Pekeliling Ikhtisas yang dikeluarkan oleh Kementerian Pendidikan Malaysia secara berkala.

Menurut pekeliling dan peraturan sekolah Kementerian Pelajaran Malaysia, salah laku pelajar boleh dikategorikan kepada tiga jenis kesalahan iaitu kesalahan berat, kesalahan sederhana dan kesalahan ringan. Menurut Surat Pekeliling Ikhtisas Bil. 7/2003, telah disenaraikan kesalahan berat di sekolah yang boleh dikenakan hukuman rotan seperti kesalahan membawa, menyimpan atau menghisap dadah, bergaduh, dan biadap terhadap guru. Hukuman rotan merupakan hukuman dera (corporal punishment) yang boleh digunakan sebagai strategi kawalan disiplin bagi pelajarpelajar yang melakukan kesalahan yang dinyatakan. Ia merupakan hukuman yang sangat berkesan kerana memberikan kesakitan kepada penerimanya supaya tidak mengulangi perbuatan yang sama. Namun, tindakan merotan merupakan langkah terakhir setelah pelbagai tindakan diambil seperti nasihat kepada pelajar dan kaunseling gagal. ${ }^{15}$ Hukuman rotan menjadi suatu perkara yang amat dititiberatkan oleh pelbagai pihak seperti Kementerian Pelajaran Malaysia (KPM), pihak guru dan ibu bapa. Tambahan lagi, keberkesanan merotan pelajar dalam mengawal disiplin pelajar juga sering dipertikaikan.

\section{PROSEDUR HUKUMAN ROTAN MENURUT KEMENTERIAN PELAJARAN MALAYSIA}

Beberapa garis panduan atau prosedur operasi standard (SOP) dikeluarkan oleh pihak Kementerian Pendidikan Malaysia sebagai panduan pentadbir dan guru sekolah dalam melaksanakan hukuman rotan. Kuasa merotan murid telah disediakan oleh Kementerian Pendidikan Malaysia sejak sekian lama. Kuasa ini telah diperuntukkan dalam Peraturan-peraturan Pelajaran (Disiplin Sekolah) 1959, di bawah Ordinan Pelajaran 1957. Dalam Peraturan 6 dinyatakan secara jelas bahawa:

"Guru Besar sesebuah sekolah boleh dari semasa ke semasa, tertakluk kepada apa-apa syarat dan hal

15 James Ang Jit Eng. Pengurusan Bilik Darjah: Strategi-strategi Mewujudkan Komuniti Pembelajaran Berkesan (Kuala Lumpur: PTS Professional, 2014), 182. 
yang difikirkannya patut, mewakilkan kuasa disiplin sekolah dan kuasa menjalankan hukum kepada guru-guru lain di sekolah itu atau kepada murid-murid yang ditetapkan olehnya bagi maksud itu, tetapi kecuali yang disebut di atas tidak seorang pun guru atau murid boleh menjalankan kuasa itu melainkan dengan arahan tertentu,"

Berdasarkan peruntukan di atas, Kementerian Pendidikan Malaysia telah menetapkan bahawa guru besar atau pengetua adalah orang yang telah dipertanggungjawabkan dalam urusan pelaksanaan hukuman terhadap murid. Walau bagaimanapun, penurunan kuasa boleh dibuat oleh guru besar atau pengetua kepada guru-guru lain yang dilantik dan guru yang dipertanggungjawabkan mestilah mengetahui tatacara yang telah ditetapkan dan surat penurunan kuasa juga hendaklah dikeluarkan kepada guru tersebut. Perkara ini jelas dinyatakan dalam Peraturan-peraturan Pelajaran (Disiplin Sekolah) 1959, di bawah Ordinan Pelajaran 1957.

Menurut seksyen 91 (g) Akta kanak-kanak 2001, Kanakkanak lelaki berumur 10 hingga 18 tahun boleh dikenakan hukuman sebat dengan menggunakan 'rotan ringan' $(<0.5$ inci atau $12 \mathrm{~mm}$ ) sehingga 10 kali sebatan. Dalam seksyen 92 (b), akta yang sama, perotan perlu mengenakan kekuatan yang sederhana tanpa mengangkat tangannya melebihi kepalanya supaya tidak melukakan kulit murid yang dirotan ${ }^{16}$. Berdasarkan peruntukan tersebut, pelaksanaan hukuman rotan telah dijelaskan dalam Peraturan 5 Ordinan Pelajaran 1957 iaitu terdapat larangan hukuman rotan kepada murid perempuan dan sekiranya hukuman kepada pelajar lelaki adalah dihadkan kepada merotan dengan rotan yang ringan di tapak tangan atau pun di punggung yang berlapik dengan pakaian. Sehubungan itu, pelaksanaan hukuman rotan di khalayak sama ada di perhimpunan atau di bilik-bilik yang sedang berlangsung proses pengajaran dan pembelajaran adalah dilarang ${ }^{17}$. Tindakan sedemikian akan menjatuhkan maruah serta menimbulkan kesan negatif yang lebih besar terhadap perkembangan keperibadian seorang murid.

16 James Ang Jit Eng. Pengurusan Disiplin Murid (Kuala Lumpur: PTS Professional, 2011), 231.

17 Surat Pekeliling Ikhtisas Bil. 7/2003. 
Selepas hukuman dijalankan, pihak guru besar atau pengetua perlu mencatatkan hukuman yang dikenakan dan direkodkan dengan menyatakan jenis salah laku, bilangan sebatan, bahagian anggota yang dirotan, nama dan tandatangan perotan berserta saksi semasa hukuman rotan dilaksanakan ${ }^{18}$ dan rekod tersebut perlulah disimpan secara sulit.

\section{KEARIFAN TEMPATAN DALAM PENDIDIKAN KANAK- KANAK DI MALAYSIA}

Bagi menjamin hak kanak-kanak, Perhimpunan Agung Pertubuhan Bangsa-bangsa Bersatu telah menerima pakai beberapa ketetapan dalam Konvensyen Hak Kanak-kanak pada 20 November 1989. Konvensyen ini mengandungi 54 perkara yang menekankan kepentingan dan hak kanak-kanak. Antara hak yang terkandung dalam konvensyen tersebut ialah hak untuk hidup, hak untuk membangun peribadi melalui pelajaran, hak untuk dilindungi daripada semua jenis penganiayaan dan hak untuk mengambil bahagian. Malaysia telah menerima konvensyen ini pada tahun 1995 dengan beberapa reservasi. Antara perkara yang tidak diterima pakai di Malaysia adalah perkara $1,{ }^{19} 2,{ }^{20} 7,{ }^{21} 13,{ }^{22} 14,{ }^{23}$ $15,{ }^{24} 28(1)(\mathrm{a})^{25}$ dan $37^{26}$.

Pada tahun 2001 pada persidangan kali ke 26, Jawatankuasa Hak Kanak-Kanak telah mengeluarkan kenyataan umum berhubung perkara ke 29 (1) yang berhubung dengan pendidikan kanak-kanak yang mesti dihalatujukan kepada perkembangan personaliti, bakat, kebolehan mental dan fizikal kanak-kanak

\footnotetext{
Peraturan-peraturan Pelajaran 1959.

9 Takrifan anak.

20 Prinsip tidak mendiskriminasi.

21 Nama dan Kerakyatan.

22 Kebebasan bercakap.

23 Kebebasan berfikir dan beragama.

24 Kebebasan berpersatuan.

25 Pendidikan rendah diwajibkan dan dijadikan percuma kepada semua.

26 Negara-negara pihak hendaklah memastikan bahawa tiada kanakkanak boleh tertakluk kepada penyeksaan atau layanan atau hukuman lain yang zalim, tidak berperikemanusiaan atau menjatuhkan maruah.
} 
pada tahap potensi yang paling tinggi. Berhubung perkara ini, kenyataan umum yang dikeluarkan adalah seperti berikut:

"Children do not lose their human rights by virtue of passing through the school gates. Thus, for example, education must be provided in a way that respects the inherent dignity of the child and enables the child to express his or her views freely in accordance with article 12 (1) and to participate in school life. Education must also be provided in a way that respects the strict limits on discipline reflected in article 28 (2) and promotes non-violence in school. The Committee has repeatedly made clear in its concluding observations that the use of corporal punishment does not respect the inherent dignity of the child nor the strict limits on school discipline. Compliance with the values recognized in article 29 (1) clearly requires that schools be child-friendly in the fullest sense of the term and that they be consistent in all respects with the dignity of the child. ${ }_{27}$

Melalui kenyataan di atas, jelas bahawa perkara yang terkandung dalam Perkara 29 adalah matlamat pendidikan yang menggalakkan dan menjamin perkembangan rasa hormat bagi hak asasi manusia. Perkara ini juga menggesa keperluan pendidikan bersifat mesra pelajar dan pemerkasaan proses pendidikan yang berdasarkan prinsip yang telah digariskan. Proses pendidikan yang dimaksudkan bukan terhad kepada kandungan kurikulum sahaja tetapi merangkumi kaedah pedagogi dan suasana pembelajaran berjalan. ${ }^{28}$ Justeru, Jawatankuasa Hak Kanak-kanak ini telah menegaskan bahawa disiplin di sekolah mesti ditadbirkan mengikut cara yang selaras dengan kemuliaan kanak-kanak.

27 General Comment no. 1: The Aims of Education (article 29) (2001), daripada laman sesawang rasmi United Nations Human Rights The Office of The High Commissioner, dicapai 10 Disember 2018, https://www.ohchr.org/EN/Issues/Education/Training/Compilation/ Pages/a)GeneralCommentNo1TheAimsofEducation(article29) (2001).aspx.

Ibid. 
Dalam hal ini, hukuman dera (corporal punishment) dianggap sebagai satu bentuk tindakan yang tidak menghormati kemuliaan dan kehormatan kanak-kanak serta pendekatan yang tidak bersifat mesra pelajar.

Kesan daripada kenyataan ini, 117 buah negara di dunia ini telah mengharamkan pelaksanaan hukuman dera ke atas kanak-kanak di sekolah. Walau bagaimanapun, Malaysia masih meneruskan pelaksanaannya dengan penambahbaikan pada garis panduan pelaksanaan sepertimana yang dapat dilihat dalam Surat Pekeliling Ikhtisas Bil. 7/2003. Namun, pada tahun 2015 telah timbul satu cadangan daripada Menteri Pembangunan Wanita, Keluarga dan Masyarakat pada ketika itu untuk menjadikan hukuman rotan oleh ibu bapa ke atas anak-anak sebagai satu kesalahan jenayah. Menurut beliau, walaupun hukuman rotan merupakan sebahagian budaya masyarakat Malaysia, kerajaan perlu akur kepada Konvensyen Hak Kanak-kanak yang memandang serius perkara tersebut. ${ }^{29}$ Namun, cadangan ini mendapat bantahan daripada segenap lapisan masyarakat melibatkan mufti, tokoh masyarakat, ${ }^{30}$ ahli politik, ${ }^{31}$ persatuan guru ${ }^{32}$ dan sebagainya. Akhirnya, setelah mengambil kira pelbagai pandangan, akhbar melaporkan bahawa kerajaan tidak berhasrat untuk menjadikan rotan anak sebagai satu kesalahan jenayah sepertimana yang telah dicadangkan. ${ }^{33}$

Walaupun Malaysia tidak menerima pakai larangan pelaksanaan hukuman dera seperti rotan ke atas kanak-kanak, masyarakat Malaysia kini didapati lebih peka dan sensitif terhadap pelaksanaan

29 Rotan anak bakal jadi kesalahan jenayah, Utusan Malaysia, 24 Januari 2015.

30 Kesatuan Guru Tidak Sokong Cadangan Rotan Anak Satu Kesalahan Jenayah, 29 Januari 2015, laman sesawang rasmi IKIM.fm, dicapai 10 Disember 2018, https://ikimfm.my/kesatuan-guru-tidak-sokongcadangan-rotan-anak-satu-kesalahan-jenayah/.

31 Jangan jadikan ibu bapa penjenayah, Sinar Harian, 26 Januari 2015; Islam benarkan untuk didik anak, Sinar Harian, 28 Januari 2015.

32 Kesatuan Guru Tidak Sokong Cadangan Rotan Anak Satu Kesalahan Jenayah, 29 Januari 2015, laman sesawang rasmi IKIM.fm, dicapai 10 Disember 2018, https://ikimfm.my/kesatuan-guru-tidak-sokongcadangan-rotan-anak-satu-kesalahan-jenayah/.

33 Kerajaan tidak bercadang jadikan rotan anak sebagai kesalahan jenayah, Kosmo, 17 Mac 2015. 
hukuman ini. Kajian yang dilakukan mengenai persepsi ibu bapa terhadap hukuman rotan mendapati bahawa $60 \%$ ibu bapa di sekolah yang dikaji bersetuju bahawa guru sepatutnya dibenarkan merotan pelajar untuk tujuan disiplin dan hukuman merotan boleh mengurangkan masalah disiplin. Sebanyak 68.1\% ibu bapa bersetuju bahawa hukuman rotan masih sesuai dilaksanakan bagi kesalahan berat tertentu dan $73.4 \%$ ibu bapa juga bersetuju bahawa hukuman rotan boleh dilakukan asalkan tidak mendatangkan kecederaan. Namun, $80.9 \%$ ibu bapa berpandangan bahawa garis panduan khusus untuk merotan pelajar disediakan. ${ }^{34}$

Jelas bahawa dalam aspek mendisiplinkan anak-anak, pendekatan oleh masyarakat Melayu terdahulu dan masyarakat Malaysia melalui KPM dilihat seimbang dan sederhana. Hukuman rotan telah diterima dalam budaya masyarakat sebagai salah satu kaedah mendisiplin atau mendidik anak-anak. Hukuman ini juga masih diterima sehingga kini dan dilaksanakan di peringkat sekolah bagi menangani masalah disiplin pelajar dengan garis panduan tertentu. ${ }^{35} \mathrm{Hal}$ ini bermaksud pendekatan yang telah berakar umbi dalam kalangan masyarakat tidak terkesan dengan pendekatan global dalam aspek ini. Namun, ini tidak menghalang tindakan undang-undang diambil sekiranya guru melampaui had batas yang digariskan sehingga mendatangkan kecederaan serius kepada kanak-kanak. Dalam hal ini, mereka boleh didakwa mengikut seksyen 31(1)(a) Akta Kanak-Kanak 2001 yang memperuntukkan hukuman denda tidak lebih RM20,000 atau penjara maksimum 10 tahun atau kedua-duanya sekali.

34 Zainudin Abu Bakar dan Jani Tawil, "Persepsi Ibu Bapa Terhadap Hukuman Merotan ke atas Pelajar yang Melakukan Kesalahan Disiplin di SMK Ulu Tiram, Johor Bahru”, laman sesawang Universiti Teknologi Malaysia Institutional Repository, dicapai 10 Disember 2018, http://eprints.utm.my/id/eprint/11339/1/Persepsi_Ibu_Bapa_ Terhadap_Hukuman_Merotan_Ke_Atas_Pelajar_Yang_Melakukan_ Kesalahan_Disiplin_Di_SMK_Ulu_Tiram.pdf.

35 Hukuman Rotan Kekal Dasar Kementerian Pendidikan, Berita Harian, 15 November 2017. 


\section{PENGARUH ISLAM DALAM NILAI TEMPATAN BERHUBUNG KAEDAH PENDIDIKAN ANAK}

Jikadiamati, garispanduanyang disusun oleh KPMmemperlihatkan keselarian dengan panduan yang digariskan dalam perundangan Islam. Dalam perundangan Islam, keharusan untuk mendidik anak melalui hukuman ini dapat difahami antaranya melalui hadishadis berikut:

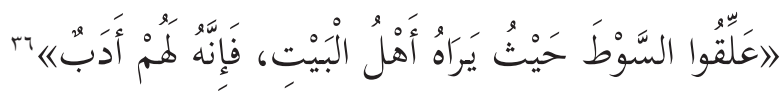

Terjemahan: Gantungkanlah rotan sehingga rotan itu dapat dilihat oleh ahli keluarga, sesungguhnya itu boleh mendidik mereka.

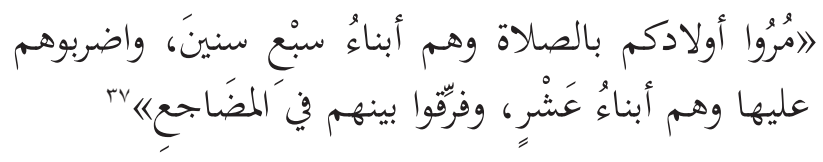

Terjemahan: Perintahlah anak-anakmu solat ketika berusia 7 tahun, dan pukullah mereka ketika berusia 10 tahun serta pisahkanlah tempat tidur mereka.

Daripada hadis yang pertama, dapat difahami bahawa wujud gesaan untuk mendidik ahli keluarga termasuk anak-anak melalui ancaman hukuman sekiranya mereka melakukan kesalahan. Dalam membincangkan maksud hadis ini, al-Munawi menjelaskan bahawa pendekatan ini boleh mendorong seseorang untuk beradab dan berakhlak dengan akhlak mulia dan melatih jiwa yang keras untuk mengamalkan nilai murni. Dalam hadis tersebut juga, dapat difahami bahawa rotan merupakan simbolik kepada ancaman hukuman yang boleh memberikan kesan kepada tingkah laku seseorang, terutamanya kanak-kanak, walaupun ia hanya

36 Abī al-Qāsim Sulaymān bin Ahmad al-Ùabrāni, al-Mu'jam al-Kab̄̄r, Bab 'Alī bin 'Abd Allāh bin 'Abbas 'an abīhi (Qāhirah: Maktabah Ibn Tamīyah, t.th), no. hadis 10671 .

37 Abū Dāwud Sulaymān ibn al-Ash'ath al-Sijistan̄̄, Sunan Ab̄̄ Dāwud, Kitāb al-solāt, Bāb fī al-had yushfa' fīhi (Riyāụ: Maktabah al-Ma'ārif li al-Nashr wa al-Tawzī', 2000), no. hadis 495. 
digantung dan tidak digunakan. ${ }^{38}$ Hadis kedua pula menjelaskan bahawa kanak-kanak yang melakukan kesalahan boleh dididik dengan menggunakan pukulan rotan bermula umur sepuluh tahun.

Melalui hadis yang dinyatakan juga, dapat difahami bahawa hukuman yang dikenakan kepada kanak-kanak yang melakukan kesalahan adalah berbentuk pendidikan ${ }^{39}$ serta bertujuan memberi pengajaran atau pemulihan ( $\mathrm{ta}$ 'dib).$^{40} \mathrm{Hal}$ yang demikian juga merupakan hak seorang bapa. Selain bapa, ibu, datuk, guru dan penjaga yang diberikan kuasa untuk mendidik anak-anak juga diberikan hak yang sama semasa anak berada dalam jagaannya. ${ }^{41}$ Dalam hal ini, garis panduan KPM juga menggariskan hal yang serupa iaitu memberikan bidang kuasa pelaksanaan hukuman hanya kepada guru tertentu sahaja. Hak melaksanakan hukuman tidak bersifat mutlak kepada semua guru.

Pelaksanaan hukuman rotan bagi mendidik anak dalam Islam bukanlah hak atau kebenaran yang diberikan secara mutlak. Ia terikat dengan syarat tertentu. Garis panduan mengenai pelaksanaannya boleh difahami melalui hadis-hadis Nabi SAW dan athar para sahabat, antaranya seperti berikut:

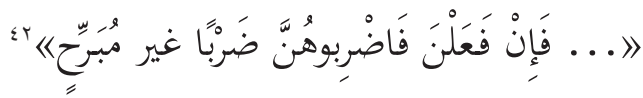

38 'Abd al-Raūf al-Munāwi, Fayḍ al-Qad̄̄r (Mișr: al-Maktabah alTijāriah al-Kubrā, t.t.), 4: 325.

39 Wahbah al-Zuhaylī, Fiqh Islām wa Adillatuhu (Dimashq: Dār al-Fikr, 2004), 7:5591.

40 Muhammad Ibn Sa'ad al-Ghāmidī, 'Uqūbah al-I'dam (Riyāẹ: Maktabah Dār al-Salām, 1992), 30. 'Alī bin Muhammad bin Habīb al-Bașri al-Baghdādī al-Māwardī, al-Ahkām al-Sulțāniah wa alWilāyāt al-Dīniyyah (Bayrūt: Dār al-Kutub al-'Ilmiyyah, t.th), 293.

41 Ibrāhīm Ibn 'Alī al-Fairūz Abādī al-Shīrāzi, al-Muhadhdhab (Bayrūt: Dār al-Kutub al-'Ilmiyyah, 1995), 3:375. Muhammad bin Ab̄̄ alAbbas Ahmad al-Ramlī, Nihāyah al-Muhtāj (Bayrūt: Dār al-Fikr li Țabā'ah, 1984), 1: 391.

42 Abū Dāwud Sulaymān ibn al-Ash'ath al-Sijistan̄̄, Sunan Ab̄̄ Dāwud, Kitāb al-Manāsik, Bāb Șifat hajjat al-nabiy (Riyāḍ: Maktabah alMa'ārif li al-Nashr wa al-Tawzī', 2000), no. hadis 1905. 
Terjemahan: ...Sekiranya mereka melakukannya, maka kamu boleh mendidik mereka (wanita-wanita itu) dengan pukulan yang tidak membahayakan.

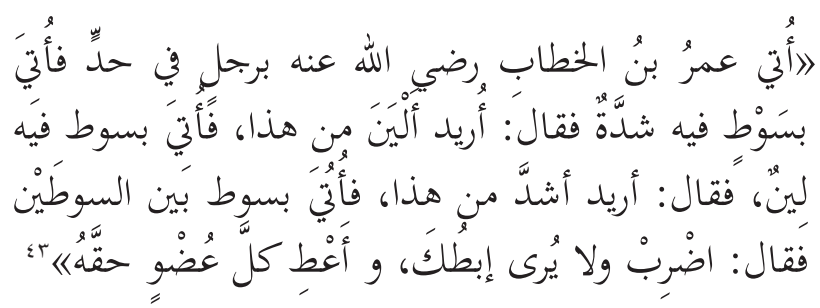

Terjemahan: Telah datang seorang tukang sebat kepada 'Umar al-Khațtāa RA. Didatangkan kepada Umar rotan yang keras. Umar berkata: Aku menghendaki rotan yang lembut daripada ini. Maka didatangkan dengan rotan yang lembut. Umar berkata: Aku menghendaki rotan yang lebih keras daripada ini. Maka didatangkan rotan yang tidak terlalu lembut atau keras. Umar berpesan: Rotanlah dan jangan diangkat tanganmu sehingga menampakkan ketiakmu. Berikanlah setiap anggota haknya.

Hadis pertama menjelaskan tentang hak suami dalam mendidik isteri. Kebenaran untuk suami mendidik isteri disyaratkan agar tidak dilakukan dengan pukulan yang kuat sehingga membahayakan. Para fuqaha menegaskan perkara yang sama juga terpakai dalam pendidikan terhadap anak-anak. Dalam athar yang berikutnya pula, dilaporkan mengenai pelaksanaan hukuman rotan ketika zaman pemerintahan Khalifah 'Umar al-Khațtāb RA. Dalam konteks ini, hukuman yang dikenakan adalah sebagai hukuman atas jenayah yang dilakukan oleh pesalah. Sungguhpun begitu, Khalifah 'Umar al-Khaț̣āb RA memerintahkan agar rotan yang digunakan dalam pelaksanaan hukuman mestilah yang bersifat sederhana iaitu tidak terlalu keras dan tidak terlalu lembut.

43 Șālih Ahmad al-Shāmī, Zawā'id al-Sunan al-Kubrā li al-Baihaq̄̄ 'ala al-Kutub al-Sittah: 'alaihi ta'līqāt al-Imāmain al-Dhahabi wa Ibn al-Turkumāni, Kitāb al-Rabi': al-Hudūd, Bab ma jāa fị Șifat alsawt wa sifat al-ḍarb (Bayrūt: al-Maktab al-Islāmī, 2010), no. hadis 7040 . 
Selain itu, beliau juga memerintahkan tukang sebat agar tidak mengangkat tangan sehingga menampakkkan ketiak atau dalam erti kata lain jangan memukul dengan pukulan yang terlalu kuat. Justeru dalam konteks pendidikan anak-anak yang mana hukuman jenayah tidak dikenakan ke atas mereka sebelum mencapai usia baligh, ${ }^{44}$ hukuman untuk mendidik lebih-lebih lagi perlu dilakukan dengan cermat dan bukan untuk menyakiti.

Perincian garis panduan pelaksanaan hukuman rotan bagi tujuan pendidikan dan pendisplinan anak-anak seterusnya diperincikan lagi oleh para fuqaha. Antaranya, (i) hukuman rotan tidak harus dilakukan pada bahagian badan yang boleh menyebabkan kerosakan bahagian itu seperti pada tengkok, muka, kemaluan, perut, dada dan kepala (ii) Merotan juga tidak

44 Menurutperundangan Islam, tanggungjawabjenayah dan hukumannya hanya akan dikenakan ke atas seseorang apabila telah memenuhi dua asas utama iaitu pesalah mempunyai daya fikir yang sempurna (al-idrak) dan pesalah melakukan kesalahan dengan pilihan sendiri atau sukarela (al-ikhtiyar). Dalam konteks kanak-kanak, kedua-dua unsur ini tidak sempurna kerana dipengaruhi oleh umur mereka. Dalam hal ini, fuqaha membahagikan penguasaan kanak-kanak terhadap dua unsur ini kepada tiga peringkat. Pertama, peringkat ketiadaan daya fikir (incidam al-idrak) iaitu golongan kanak-kanak yang belum mumaiyiz, bermula daripada umur sifar sehingga tujuh tahun. Oleh kerana daya fikir dan memilih belum ada, kanak-kanak pada peringkat ini tidak layak menerima sebarang hukuman jenayah. Peringkat kedua adalah peringkat lemah pengetahuan atau daya fikir belum sempurna (al-idrak al-dacif) iaitu golongan kanak-kanak yang dikategorikan sebagai mumaiyiz iaitu dalam lingkungan umur lapan sehingga mencapai umur baligh. Disebabkan daya fikir yang belum sempurna, golongan ini tidak layak mereka menerima sebarang hukuman jenayah. Namun, mereka boleh dikenakan hukuman untuk mendidik dan mendisiplinkan mereka seperti pukulan. Keduadua peringkat umur ini walaupun tidak boleh dikenakan tindakan jenayah, boleh dikenakan tindakan sivil sekiranya perbuatan mereka mendatangkan kemudaratan terhadap hak individu. Harta kanakkanak itu dalam peringkat ini boleh digunakan bagi membayar ganti rugi yang sewajarnya terhadap pihak mangsa. Hanya pada peringkat ketiga iaitu bermula daripada usia baligh, daya fikir seseorang dianggap sempurna dan justeru boleh dipertanggungjawabkan terhadap jenayah dan dikenakan hukuman. 
harus menyebabkan bahagian yang dirotan itu berdarah atau mendatangkan kecederaan. ${ }^{45}$ (iii) hukuman mestilah bertujuan untuk mendidik bukan untuk menyakiti (iv) hukuman didikan ini dilakukan bagi kesalahan yang telah dilakukan oleh kanakkanak tersebut bukan bagi kesalahan yang dikhuatiri akan dilakukannya (v) hukuman yang dikenakan diterima sebagai satu bentuk hukuman bagi mendidik anak-anak mengikut uruf masyarakat (vi) hukuman tidak dilakukan secara melampau dan berlebih-lebihan. Jika syarat-syarat ini tidak dipatuhi, maka pihak yang melakukannya boleh diambil tindakan atas kecederaan yang menimpa kanak-kanak tersebut.

Secara umum, boleh disimpulkan bahawa ajaran Islam dalam aspek pendidikan anak ini telah mempengaruhi nilai dan budaya masyarakat Melayu. Garis panduan yang dirumuskan oleh para fuqaha berkenaan pelaksanaan hukuman ke atas anak ini pula, dipercayai menjadi pertimbangan serta rujukan masyarakat tempatan melalui garis panduan yang dikeluarkan oleh KPM. Segala peraturan dan prosedur operasi standard yang ditetapkan adalah menepati perundangan Islam dan dari semasa ke semasa wajar ditambah baik bagi menjamin pembentukan peribadi anakanak yang unggul tanpa melanggar kehormatan dan hak kanakkanak yang diiktiraf oleh Islam.

\section{KESIMPULAN}

Perbincangan mengenai kearifan tempatan dalam pendidikan kanak-kanak dalam kertas ini telah dibincangkan melalui dua perspektif iaitu dimensi nilai dan dimensi pengambilan keputusan tempatan. Budaya pendisplinan anak-anak melalui hukuman dalam kalangan masyarakat Melayu terdahulu jelas dapat difahami melalui peribahasa yang berkaitan. Daripada aspek dimensi nilai, dapat dirumuskan bahawa nilai dan pegangan yang terkandung dalam peribahasa Melayu tersebut dipengaruhi oleh ajaran Islam yang datang ke Tanah Melayu seawal abad ke 15 mengikut catatan sejarah. Falsafah pendidikan orang Melayu yang dijelmakan melalui peribahasa juga lebih mirip kepada falsafah pendidikan

45 'Abd Allāh Nāṣị̣ 'Ulwān, Tarbiyyat al-Awlād fì al-Islām (Qāhirah: Dār al-Salām li al-Ṭabā'ah wa al-Nashr wa al-Tawzī‘ , 1992), 2: 727728. 
Islam yang menekankan pembentukan peribadi. Justeru, kaedah hukuman bagi mendisiplinkan anak telah berakar umbi dalam kalangan masyarakat bermula melalui pendidikan tidak formal oleh ibu bapa dan diikuti dengan guru melalui pendidikan formal di madrasah dan pondok yang merupakan institusi pendidikan awal dalam sejarah masyarakat Melayu. Malah, kaedah ini masih diterima oleh kebanyakan ibu bapa di Malaysia jika dilaksanakan mengikut kaedah yang sewajarnya.

Daripada aspek dimensi pengambilan keputusan tempatan, kebijaksanaan kerajaan melalui Kementerian Pendidikan Malaysia (KPM) jelas apabila berjaya mempertahankan nilai dan budaya tempatan daripada pengaruh nilai barat. Undangundang antarabangsa mengenai larangan mengenakan hukuman dera ke atas pelajar-pelajar di sekolah telah diseimbangkan oleh KPM melalui pelbagai garis panduan seperti Peraturanperaturan Pelajaran (Disiplin Sekolah) 1959, buku-buku panduan pengurusan disiplin yang diterbitkan oleh KPM dan surat-surat Pekeliling Ikhtisas yang juga dikeluarkan oleh KPM secara berkala. Dalam hal ini, jelas bahawa nilai budaya dan kearifan masyarakat tempatan terdahulu bukan sahaja dikekalkan, malah telah diterjemahkan melalui perundangan pendidikan yang bersifat sederhana dan seimbang dalam membenarkan pelaksanaan hukuman namun tidak smpai menzalimi murid atau pelajar yang dihukum.

\section{RUJUKAN}

'Abd Allāh Nāṣih 'Ulwān. Tarbiyyat al-Awlād fì al-Islām. Qāhirah: Dār al-Salām li al-Ṭabā'ah wa al-Nashr wa al-Tawzī', 1992.

Abdullah Hassan dan Ainon Mohd. Kamus Peribahasa Kontemporari. Bentong: PTS Publications \& Distributors Sdn. Bhd, 2003.

Ab̄̄ al-Qāsim Sulaymān bin Ahmad al-Ủabrāni. al-Mu'jam alKabīr. Jilid ke-10. Qāhirah: Maktabah Ibn Tamīyah, t.th.

Abū Dāwud Sulaymān ibn al-Ash'ath al-Sijistanī. Sunan Abī Dāwud. Riyāḍ: Maktabah al-Ma'ārif li al-Nashr wa alTawzī‘, 2000.

al-Ghāmidī, Muhammad Ibn Sa'ad. 'Uqūbah al-I'dām. Riyāḍ: Maktabah Dār al-Salām, 1992. 
'Ali bin Muhammad bin Habīb al-Bașri al-Baghdādi al-Māwardi. al-Ahkām al-Sulțāniah wa al-Wilāyat al-Dìniyyah. Bayrūt: Dār al-Kutub al-'Ilmiyyah, t.th.

al-Munāwi, 'Abd al-Rauf. Faỵ̣ al-Qadīr. Jilid ke-4. Mișr: alMaktabah al-Tijāriah al-Kubrā, t.th.

al-Ramli, Muhammad bin Abī al-Abbas Ahmad. Nihāyah alMuhtāj. Jilid 1. Bayrūt: Dār al-Fikr lițtābā'ah, 1984.

al-Shīrāzī, Ibrahīm Ibn 'Ali al-Fayrūz Abādi. al-Muhadhdhab. Jilid ke-3. Bayrūt: Dār al-Kutub al-'Ilmiyyah, 1995.

Islam benarkan untuk didik anak, Sinar Harian, 28 Januari 2015.

James Ang Jit Eng. Pengurusan Bilik Darjah: Strategi-strategi Mewujudkan Komuniti Pembelajaran Berkesan. Kuala Lumpur: PTS Professional, 2014.

James Ang Jit Eng. Pengurusan Disiplin Murid. Kuala Lumpur: PTS Professional, 2011.

Jangan jadikan ibu bapa penjenayah, Sinar Harian, 26 Januari 2015.

Kerajaan tidak bercadang jadikan rotan anak sebagai kesalahan jenayah, Kosmo, 17 Mac 2015.

Mohd Izuddin Ramli dan Mohamad Zaini Abu Bakar. "Kearifan Tempatan dalam Institusi Sekolah Pondok di Malaysia." dalam Ilmu, Tradisi dan Kelestarian dalam Kearifan Tempatan, ed. Salasiah Che Lah dan Norizan Esa, 41. Pulau Pinang: Penerbit Universiti Sains Malaysia, 2015.

Mohd. Ismail Othman. Undang-undang untuk Pengetua dan Guru Besar. Kuala Lumpur: PTS Professional, 2008.

Nasrul Hisyam Nor Muhamad \& Zarina A Rashid, "Peraturan dan Undang-Undang Kawalan Disiplin Murid di Malaysia", dicapai 17 Mei 2019, Malaysian Online Journal of Education (2017), 1-11.

Peraturan-peraturan Pelajaran 1959.

Portal rasmi IKIM.fm. Capaian 10 Disember 2018. Kesatuan Guru Tidak Sokong Cadangan Rotan Anak Satu Kesalahan Jenayah. 29 Januari 2015. https://ikimfm.my/kesatuanguru-tidak-sokong-cadangan-rotan-anak-satu-kesalahanjenayah/ 
Portal rasmi Pusat Persuratan Rujukan Melayu. Capaian 6 Disember 2018. http://prpm.dbp.gov.my/ Cari1 ?keyword=buluh\&d $=287324 \&$.

Portal rasmi United Nations Human Rights The Office of The High Commisioner. Capaian 10 Disember 2018 General Comment no. 1: The Aims of Education (Article 29). (2001). https://www.ohchr.org/EN/Issues/Education/Training/ Compilation/Pages/a)GeneralCommentNo1 TheAimsofEdu cation(article29)(2001).aspx

Rabiatul Adawiyah et. al. "Pendekatan Penerapan Pendidikan Nilai Menerusi Pendidikan Tidak Formal Masyarakat Melayu Terdahulu." dalam Merakayasa Kearifan Tempatan: Budaya, Pelancongan, Arkeologi dan Sejarah, ed. Nazaruin Zainun dan darlina Md. Naim, 47-49. Pulau Pinang: Penerbit Universiti Sains Malaysia, 2014.

Rotan anak bakal jadi kesalahan jenayah, Utusan Malaysia, 24 Januari 2015.

Șāliḥ Ahmad al-Shāmī. Zawā'id al-Sunan al-Kubrā li al-Baihaqi 'ala al-Kutub al-Sittah: 'alaihi ta'līqāt al-Imāmain alDhahabī wa Ibn al-Turkumāni. Jilid ke-3. Bayrūt: Maktab al-Islāmī, 2010.

Surat Pekeliling Ikhtisas Bil. 7/2003.

Wahbah al-Zuḥaylī. Fiqh Islām wa Adillatuhu. Jilid ke-7. Dimashq: Dār al-Fikr, 2004.

Wan Rafaei Abdul Rahman, "Peribahasa Sebagai Sumber Epistimologi Melayu: Satu Singkapan Terhadap Etika Kerja", dalam Prosiding Simposium Pengetahuan Pribumi anjuran Akademi Pengajian Melayu Universiti Malaya pada 15 April 2015, 70.

Zainudin Abu Bakar dan Jani Tawil, "Persepsi Ibu Bapa Terhadap Hukuman Merotan ke atas Pelajar yang Melakukan Kesalahan Disiplin di SMK Ulu Tiram, Johor Bahru", laman sesawang Universiti Teknologi Malaysia Institutional Repository, dicapai 10 Disember 2018, http://eprints.utm. my/id/eprint/11339/1/Persepsi_Ibu_Bapa_Terhadap Hukuman_Merotan_Ke_Atas_Pelajar_Yang_Melakukan_ Kesalahan_Disiplin_Di_SMK_Ulu_Tiram.pdf. 
Jurnal Fiqh, Vol. 16 No. 1 (2019) 83-104

Zaitul Azma. Peribahasa Melayu: Penelitian Makna dan Nilai. Serdang: Penerbit Universiti Putra Malaysia, 2011. 